\title{
The Youth Academy Café: Gaining the Voices and Perspectives of Youth through Conversation
}

\author{
Michelle Cook, Joyce Levingston, Stanley Ebede, Brian Hadley, Younis Al-Hassan, \\ Dong Yub Back, Marie Adebiyi*, Christopher R. Edginton
}

Department of Health, Recreation and Community Services, University of Northern Iowa, Cedar Falls, IA, USA

Email: *elombmaa@uni.edu

How to cite this paper: Cook, M., Levingston, J., Ebede, S., Hadley, B., Al-Hassan, Y., Back, D. Y., Adebiyi, M., \& Edginton, C. R. (2019). The Youth Academy Café: Gaining the Voices and Perspectives of Youth through Conversation. Sociology Mind, 9, 1-16. https://doi.org/10.4236/sm.2019.91001

Received: September 11, 2018

Accepted: November 3, 2018

Published: November 6, 2018

Copyright (c) 2019 by authors and Scientific Research Publishing Inc. This work is licensed under the Creative Commons Attribution International License (CC BY 4.0)

http://creativecommons.org/licenses/by/4.0/

\begin{abstract}
The purpose of this article was to gain the voices of youth and to help community leaders from youth service organizations developing an understanding of the concerns and issues facing young people in today's ever changing society. Youth voices are a valuable resource for community agencies who serve the population. Through implementing the World Café methodology, an environment was constructed to create meaningful conversation in a comfortable, mutually respectful and engaging environment. This qualitative study recruited 43 individuals (14 males and 29 females, age: 14 - 18) to discuss the following seven questions: 1) Can you discuss the ways you think the community can enhance the empowerment of youth? 2) How can we help young people live a life of meaning? 3) What do you see as a barrier or obstacle in reaching your post high school goals and how can we help? 4) In what ways do you think social media can be employed to understand the issues and concerns of youth? 5) What specific concerns in our community do young people face? What can we do to help you handle these concerns? 6) What do you think the community can do to enhance your wellbeing? And 7) What can the community do to assist young people in finding employment? Ultimately, the findings urge that program planners, government officials and policy makers as well as the citizenry, should continuously provide a respectful, meaningful and professional platform for youths to contribute their voice. As youth leaders, the sense of responsibly to appropriately lead young people should not minimize the importance of providing that sense of place to the youth. The five major themes that have emerged include: 1) empowerment and the need for expression; 2) the importance of living a meaningful life; 3) improving ways of knowing and awareness of opportunities; 4) lack of a ga-
\end{abstract}


thering places; 5) the impact of social media; and 6) need to promote wellness. Conclusion and implications are discussed.

\section{Keywords}

Youths, Gaining Youth Voices, Youth Academy Café, World Café, Community

\section{Introduction}

One's youth can be conceived of as a period of growth and role experimentation between childhood and adulthood (Keniston, 1971). Youth represents a wide range of family backgrounds, educational endeavors, family makeup, health behaviors, employment experiences, and leisure pursuits that depart from the immediate past generations (Nugent, 2005). Such differences create challenges for program planners, educators, policy makers and the society as a whole. Therefore, it is important to seek the perceptions and voices of youth to seek interventions and preventions for programs.

Cunningham \& Rious (2015) have suggested that "most adolescents desire to be a part of social change, want to be involved in activities that engage their hearts and minds, and are actively involved in planning their respective futures" (p. 86). However, as Hall (1904) has written, this is a period of time in one's life which is inherently a time of "storm and stress". It is a time of growth and development "when all young people go through some degree of emotional and behavioral upheaval before establishing a more stable equilibrium in adulthood" (Arnett, 2006: p. 186). This paper reports in the process known as the "Youth Academy Café" aimed at promoting dialogue and conversations among youth.

\subsection{Understanding the Term "Youth"}

Defining the term "youth" is a quite diverse, complex and elusive task. As Jn Baptiste and Jalloh (2014) have suggested, definitions of youth are fluid and arbitrary. Seemingly, there are no universal definitions of this term. Sasse (2017) reminds us that "ancient Roman law explicitly divided the three stages of youth before adulthood into seven-year segments: Infantia (birth through age 6), pueritia (7 to 13), and pubertas (14 to 20) (pp. 14-15). During this time period, individuals move from a stage of dependence to independence (UNESCO, 2017). The famous psychologist, G. Stanley Hall, is often credited with crafting the concept of "adolescence" which we refer to the passage of time between childhood and adulthood (1904). Again, as Sasse (2017) writes, "child psychologists, Erik Erikson in the 1950s framed adolescence as a 'moratorium on adulthood', a time for individuals to pause in order to experiment and develop their identities, increasingly independent of their parents" (p. 15).

As there are no widely accepted definitions of youth, the meaning can vary in 
context and within cultures. The United Nations Department of Economic and Social Affairs defines "youth as those persons between the ages of 15 and 24 years, without prejudice to other definitions by Member States" (2013, p. 1). However, three examples serve as a testament to the cultural differences in defining the term youth. In Thailand youth ages range from 15 - 25 (Brown, Larson, \& Saraswathi, 2002). In the Philippines, youth represents those who 15 - 30 years of age and the African Union (2009) defines youth as individuals between the ages on 15 and 35. Pathways for Youth, an American-based nonprofit organization focused on the welfare of at-risk individuals defines youth as "those under 25 years old in three stages: early adolescence (under 14), middle adolescence $(15$ - 17), late adolescence and early adulthood (18 - 24)" (2018, p. 1).

\subsection{Youth Challenges and Pressures}

Today's youth face many social, psychological, economic and spiritual tests. These challenges can include emerging technological advances, social media, diversity and inclusion, living a life of meaning, bullying, cyberbullying, violence, obesity, and changes in familial make-up, growing up too fast, addictions, and others. The challenges of technological advances alone changes education greatly in that "school fosters just-in-case learning while technology fosters just-in time learning" (Collins \& Halverson, 2018: p. 3). Youth are always connected through a device; however, face to face, personal communication is not occurring as often. Cultural changes include more learning taking place from peer to peer as opposed to adult to peer. Isolation is a big concern among youth with the advances of technology.

Sasse (2017) describes the current generation of youth as being crippled with too much kindness from the older generation and suffering from a lack of character due to the absence of hard work. Will (2017) in reviewing Sasse's book describes the author's opinion of youth as "adolescents spending scores of hours a week on screen time with their devices acquire 'a zombie-like passivity' that saps their 'agency"' (para. 5). Will further notes that youth are "susceptible to perpetual adolescence, and ill-suited to the velocity of life in an accelerating world of shorter job durations and the necessity of perpetual learning" (2017, para. 5).

Generally, "youth" are encircled by predominantly negative images such as being seen either as a source of problem or they are the problem (Roche et al., 2004). There are a number of challenges to the health of youth. The mental health of youth is a rising concern. Youth today are impacted by increased depression, suicide, anxiety, hopelessness, lack of sleep and social isolation. This phenomenon is known has cut across other cultures and tribes around the world.

The health of youth is seemingly on decline due to factors such as lack of physical activity, obesity as well as poor nutrition. Youth face increased violence in their environments including bullying and efforts aimed at intimidation from 
their peers. Fear has been instilled in today's youth as a result of increasing amounts of mass shooting and other terrorist efforts in their academic environment. Drug abuse; including the use prescription opiates, marijuana, household cleaners, as well as binge alcohol consumption are also challenges faced by youth today. Further, youth are pressured to perform well in the school setting as well as in their extracurricular school activities. Last, as one's youth is a time of growth and change it is an often a period of social awkwardness and challenge.

\subsection{Gaining Youth Voices}

Youth voices are important no matter the time frame in society because this population is the future. Youth should have the opportunity to contribute in meaningful ways to the dialogue and conversation that impact their lives. Their voices are legitimate and need to be heard and understood. The idea of thinking together and making meaning reflects the notion of active and constructive engagement. By hearing the voices of youth, it is also a way of involving them in actively participating in their community. It is important for youth to engage in collaborative inquiry and the co-creation of ideas and concepts. Embracing this significant population of society adds to its resource base. Sethi (2010) has offered a reflection from a youth regarding the importance of their voice. He offers the following: "[Youth voices] gives us a sense of responsibility and makes us rise to the occasion and really start leading. As noted, the purpose of this article is to report on a strategy aimed at hearing the voices of youth in a framework referred to as the Youth Academy Café. The process employed will be fully described as well as an abridged analysis of the findings.

\subsection{Purpose of Study}

The purpose of this article was to gain the voices of youth and help leaders understand better ways they can assist young people to make meaning of the overarching aspects of life. Also, the project aimed at providing youths voice as a resource that will assist youth leaders to better apply their sense of responsibility to lead young.

\section{Methods}

This research involves the use of youth operating in focus groups (Creswell, 2014). According to Creswell this approach "allows the researcher control over the line of questioning" (p. 191). The process enables information to be collected in a designated place and then filtered through the views of the interviewees. The qualitative approach to inquiry involved collecting the raw data from recorders which included transcripts and notes, hand coding the data and then identifying interrelated themes. Utilizing phenomenological strategy to identify the essence of human experiences (Creswell, 2014: p. 245), this process enabled the researchers to discover and interpret emerging patterns among the individuals participating in the study. 
The event utilized the World Café method for conducting "a living network of collaborative dialogue" (World Café Foundation, 2015). Basically the World Café procedures involve seven design principals including: 1) setting the context, 2) creating hospital space, (exploring questions that matter, 3) encouraging everyone's contribution, 4) connecting diverse perspectives, 5) listening together for patterns and insights and 6) sharing collective discoveries.

\subsection{Participants}

The participants were drawn from two high schools in a Midwestern community in the United States with an overall population of slightly over 65,000 individuals. Both high schools enrolled students in grades 9 - 12. One high school has an enrollment of 1007 individuals and included portions of minority students that were higher than state averages. The make-up of the school enrollment included 49\% White, 33\% African-American, 11\% Hispanic, 5\% Multiracial and 2\% from other races. The enrollment included a significant number of students of Bosnian ethnicity (Waterloo Schools at a Glance, 2015). The second high school enrolled 1638 individuals and included 60\% White, 18.5\% African-American, $10 \%$ Hispanic, 4.6\% Multiracial, $4.5 \%$ Asian and 2.4\% from other races (Waterloo Schools at a Glance, 2015).

Forty-three individuals participated in the event. There were 14 males and 29 females. Participants ranged in age from $14-18$ with 8 individuals between the ages of 14 and 15 . There were 14 individuals who were 16 year old and 15 individuals who were 17 years old. There were 4 individuals who were age 18. One participant did not report their year of birth. The number of individuals participating was roughly divided evenly between both of the high schools.

Participants were organized into seven groups and discussion on the questions ensued with students rotating after approximately 20 or 30 minutes of discussion. Each table included a host or facilitator and a recorder. Questions that were explored included the following: 1) Can you discuss the ways you think the community can enhance the empowerment of youth? 2) How can we help young people live a life of meaning? 3) What do you see as a barrier or obstacle in reaching your post high school goals and how can we help? 4) In what ways do you think social media can be employed to understand the issues and concerns of youth? 5) What specific concerns in our community do young people face? What can we do to help you handle these concerns? 6) What do you think the community can do to enhance your wellbeing? And 7) What can the community do to assist young people in finding employment?

In the World Café process, the procedure known as the Harvest enables subgroups to distill their ideas into broader themes (Brown \& Isaacs, 2005). Collective discoveries, reflections, and insights are shared within the individual tables and collectively at the end of the event. These observations are often recorded graphically on white board, so the entire group can view the distilled comments. 


\subsection{Findings}

From the Harvest, several general themes emerged. For this Youth Academy Café which focused high school students, the following themes emerged including: 1) empowerment and the need for expression 2) the importance of living a meaningful life; 3) improving ways of knowing and awareness of opportunities; 4) lack of a gathering place; 5) the impact of social media; and 6) need to promote wellness. Table 1 provides a brief synopsis of the salient quotes in each of the themes.

Empowerment and the Need for Expression

Empowerment can be thought of as providing authority or power to an individual or group of individuals to engage is some type of activity. The process of empowerment enables individuals to become stronger and more confident and provides them with a modicum of control of their life and their future. It also provides opportunities for them to exercise their rights as youth in society. According to Christens and Peterson (2012) the time is ripe for greater consideration of youth and adolescents' actions and that empowerment theory provides a framework for understanding the outcomes and actions of young people in civic or the sociopolitical domain. Building on the work of Rappaport (1987) they define empowerment as a "mechanism by which people, groups and communities gain control over their affairs" (p. 623).

Emphasizing the importance of empowerment, the individuals in this study noted that it was important to "give power to older youth to help younger people." The concept of empowerment resonated effectively with the students participating in the Youth Academy Café. The students noted that it was important for their voices to be heard and acted upon. As Edginton, Kowalski and Randall (2005) noted, "youth development best occurs through some form of engagement within which individuals have some say in their development" (p. 4). These authors go on to note that "simply stated, youth need a voice ... to assist them in development" (p. 4).

Table 1. Themes and salient quotes.

\begin{tabular}{|c|c|}
\hline Themes & Salient Quotes \\
\hline empowerment and the need for expression & "give power to older youth to help younger people." \\
\hline importance of living a meaningful life & $\begin{array}{l}\text { "respect, support and listening to their points of view." } \\
\text { "everything is going to be okay." }\end{array}$ \\
\hline $\begin{array}{l}\text { improving ways of knowing and awareness } \\
\text { of opportunities }\end{array}$ & $\begin{array}{l}\text { "practical ways of communicating with greater } \\
\text { empathy." "respect, support and listening." "extrinsic } \\
\text { motivators" }\end{array}$ \\
\hline lack of a gathering place & "There is no place to gather" \\
\hline impact of social media & $\begin{array}{l}\text { "Facebook is older and Twitter is for real." "Students } \\
\text { noted they did not take social media seriously" }\end{array}$ \\
\hline need to promote wellness & $\begin{array}{l}\text { "the importance of promotion harmony, reducing } \\
\text { violence, reduce rivalries and tension, and creating new } \\
\text { interactions" }\end{array}$ \\
\hline
\end{tabular}




\section{Importance of Living a Meaningful Life}

One of the questions explored by the participants was the "importance of living a meaningful life" (MacKenzie \& Baumeister, 2014: pp. 25-37). Following the discussion of the youth in this study, it was clear that youth today often experience meaninglessness and yearn for purpose. Satisfying one's needs and wants can increase happiness but may be largely irrelevant to meaningfulness (Baumeister, Vohs, Aaker, \& Garbinsky, 2013). The search for meaning in the lives of youth is the quest for becoming (Edginton, Kowalski, \& Randall, 2005). As Larsen (2000) noted that positive youth development is a process whereby "adolescents become motivated, directed, socially competent, compassionate, and psychologically vigorous adults" (p. 170). In other words, one's youth or adolescence is a time during which individuals find themselves, become motivated, competent and develop their life skills. When youth are bored, they lack meaning in their lives and develop a malaise that impacts upon their positive life trajectory. "A central question of youth development is how to get adolescents' fires lit, how to have them develop the complex of dispositions and skills needed to take charge of their lives" (p. 170). Edginton, Kowalski, \& Randall (2005) write that "youth strive to belong to a group, to feel a sense of worth and inclusion that embraces them for who they are (p. 5). Youth development helps individuals in their search for identity. As Edginton (2000, p. 143) noted,

Youth ask the question consistently. "What will I become when I become who I am to be? ...youth are capable of learning, growing and perfecting themselves ... to live and learn is to always be in the process of becoming ... a continuous process ... a part of the search for one's meaning in life.

Participants in this recent Youth Academy Café indicated that meaning in their lives comes from individuals giving them "respect, support and listening to their points of view." They also noted that the ability to express something you can't say otherwise is a way of affirming meaning in their lives or asserting that "everything is going to be okay." Conversations and dialogue found in the Youth Academy Café were viewed as courageous and valuable and provided opportunities for students to express a voice. Thus, this process gave the students opportunity to gain additional meaning in their lives through conversation. As others listened, their essence was affirmed and valued.

Improving Ways of Knowing and Awareness of Opportunities

Participants suggested that it was important for them to improve their ways of gaining knowledge and awareness of opportunities. Positive youth development strategies assist individuals as they progress through life. It is the "opportunity to discover and develop talents in a variety of areas, as well as learning how to interact socially" (Edginton, Kowalski, \& Randall, 2005: p. 10). As youth are exposed to many different opportunities and challenges, their personalities, lifestyles, and future behaviors are formed and shaped. Community youth development programs often expand the opportunities for youth to acquire personal and social assets and to "experience the broad range of features of positive deve- 
lopmental settings" (Eccles \& Gootman, 2002: p. 8).

Eccles \& Gootman (2002: pp. 27-28) have suggested that there are many assets that enable positive personal and social developments. Among these: 1) physical and psychological safety and security; 2) structure that is developmentally appropriate; 3) emotional and moral support; 4) opportunities for adolescents to experience supportive adult relationships; 5) opportunities to learn how to form close, durable human relationships with peers that support and reinforce healthy behaviors; 6) opportunities to feel a sense of belonging and being valued; 7) opportunities to develop positive social values and norms; 8) opportunities for skill building and mastery; 9) opportunities to develop confidence in one's abilities to master one's environment (a sense of personal efficacy); 10) opportunities to make a contribution to one's community and to develop a sense of mattering; and 11) strong links between families, schools, and broader community resources. These features often work together in synergistic fashion. As Hamilton, Hamilton and Pittman (2004: p. 11) have offered opportunities should be available to all-to learn, explore, play, express oneself.”

In the Youth Academy Café participants identified a need to gain additional knowledge regarding finance. They emphasized the importance of gaining knowledge of "practical ways of communicating with greater empathy." In addition, the participants noted the significance of creating program opportunities that endorse the importance of "respect, support and listening." The youth also suggested that intrinsic motivators should be identified rather than extrinsic motivators such a money to encourage their participation in worthwhile projects.

Lack of a Gathering Place

A major concern echoed by participants was the need for them to have a gathering place. As they noted, "There is no place to gather" and further, such gathering places should be free to attend. As these were high school students, they noted no youth centers or clubs are available in the local community. Youth need a place where they can meet to share their common interests and engage each other in social dialogue and interaction.

Gathering places serve as refuges for youth; they are often viewed as safe environments. Often cafes, coffee shops, community centers, youth centers, and shopping malls are places where youth hangout. Evans (2007) suggests the strength of individuals who make up a community are "collections of people who feel connected, responsible, supported and influential" (p. 697). The author goes on to note that we should "make considerable effort to create environments for and with young people that promote the development of these characteristics" (p. 697). When youth have a place within which to build community it gives them voice and resonance, some power and influence and adequate support and challenge (Evans, 2007).

Impact of Social Media

Social networking sites or any internet web site that allows social interaction 
through the computer, gaming sites, videos and blogs can be considered a social media site. Examples include Facebook, Instagram, Snapchat, Twitter, YouTube, gaming sites and virtual reality programs. The social media sites have grown exponentially and are a "portal for entertainment and communication" for today's youth (O’Keeffe \& Clarke-Pearson, 2011: p. 800). However, not all the social media sites are healthy or positive environments for youth.

Social media or social networking sites may benefit youth through enhancing communication with others, meeting or connecting with others who have shared interests, creating a social connection, improving technical skills and offering a chance for youth to become involved in activities such as politics or community service or advocacy. In other words, social media can improve one's social capital. Putnam defined the concept of social capital as our connections with one another, how we share information, bonding and bridging of our social networks whether the individuals in the network are similar or diverse, and how individuals foster a collective sense community (Putnam, 2017).

An important facet of wellbeing among youth is peer acceptance and self-actualization or self-acceptance. A critical time in an individual's life is the high school years where youth often measure their worth based on how others see or value them. Through social networking sites, use of the internet has the "potential to influence adolescents' social self-esteem and well-being" and can greatly impact their overall feelings of worth through overestimating their peer's evaluation of them and through becoming preoccupied with how they may appear from their peer's viewpoints (Valkenburg, Peter, \& Schouten 2006: p. 585). In addition, the immediate feedback and evaluation available from their peers, which is also public, can greatly impact the social self-esteem or "adolescents' evaluation of their self-worth or satisfaction with three dimensions of their selves: physical appearance, romantic attractiveness, and the ability to form and maintain close friendships (p. 585).

In the Youth Academy Café, participants reflected on the value of various forms of social media, commenting that "Facebook is older and Twitter is for real." The students also noted that they do not take social media too seriously. The participants in the Youth Academy Café reported that they rely on social media for leisure and social connections in their daily lives. While the research on the impact of social networking sites is emerging, there is some indication that the use of the internet can bridge social capital or allow "one's ability to develop and maintain weak ties rather than close connections" which in the fluidity of youth (aiming for future goals, deciding upon post high school plans, etc.) can be rewarding (Steinfield, Ellison, \& Lampe, 2008: p. 443).

Behaviors such as cliques, bullying, sexual experimentation, invasion of privacy issues, internet addiction and sleep deprivation can all be negative consequences of social media use. Another notable construct is that teenagers use different apps for various purposes including communicating with "family members, finding out what's happening after school or this weekend, determining 
what's cool or acceptable among peers, and displaying one's identity to others" (Peer Relations Study Group University of Wisconsin-Madison, 2017, para. 8).

Need to Promote Wellness

The concept of wellness has many definitions. Dunn (1961), known as the architect of the modern wellness movement, defined wellness as "an integrated method of functioning which is oriented toward maximizing the potential of which the individual is capable" (p. 4). The National Wellness Institute created the Six Dimensions of Wellness Model which identifies physical, emotional, intellectual, spiritual, social and occupational as the areas of wellness (Hettler, 1976). Hettler noted the importance of creating a balance among the dimensions and stated that each of the dimension is interdependent. An imbalance in one area, can affect an individual's overall wellness. The busy life of a high school student can include academic stress, peer pressure, and social and cultural stressors. Hence, there is importance and value of personal wellness among high school age students.

Each dimension of wellness can be affected by the stressors that high school students face. One facet of wellness students discussed in the Youth Academy Café included physical wellness which can be defined as is described as a regular program of exercise and on-going healthy eating habits (Hettler, 1976). Students also discussed achieving physical wellness and noted that one barrier to success is the cost of programs or facilities that offer fitness programs and activities. With the decline of physical education programs in the school, educators have been encouraged to promote physical activity for the students as an activity that takes place at home or outside of the school setting. Lambdin and Erwin (2007) discussed the National Association for Sport and Physical Education (NASPE) policy which described physical educated students as individuals who "demonstrate competency in a variety of motor skills, are physically fit, and exhibit personal and social responsibility" (p. 29).

Another topic of wellness explored in the Youth Academy Café was social wellness or living in balance with one's environment and enhancing the well-being of others (Hettler, 1976). The students discussed the importance of promotion harmony, reducing violence, reduce rivalries and tension, and creating new interactions. Exposure to stressful life experiences can cause the student to react with negative health behaviors. As Edginton, Kowalski and Randall have suggested "increasingly, youth environments are punctuated with violence, crime, physical and sexual harassment, bullying and neglect" (p. 4). For youth to be healthy and develop effectively they must be free of such constraints. Teenage students whether entering high school, in the middle of their high school experience or preparing for post high school goals are possibly in the last structured school environment and must grow socially, develop self-responsibility and learn coping skills to face new challenges and stressors. Blum, Libbey, Bishop and Bishop (2004) studied health and wellness for teenagers and found that a lack of social-emotional competencies as a situation where students become less 
connected to school through the years. This lack of connection negatively affects their academic performance, behavior, and health.

\section{Discussion and Concluding Comments}

The challenges youth face includes many psychological, social, economic and spiritual tests. In the Youth Academy Café, these challenges were addressed through open ended questions addressing such topics as exploring the meaning of life, empowerment, knowing awareness of opportunities, social media, health and wellness, and creating a community through a gathering place. The voices of youth are imperative to understanding the issues and concerns this population faces. The adopted World Café format allows for comfortable discussion with and among youth, their peers and youth leaders in the community.

Living a life of meaning is a quest that is not specific to youth but often has the beginnings of its direction during this critical development time of adolescence. Edginton, Kowalski and Randall (2005) have suggested that adolescence is a process of becoming, a time of growth development and exploration wherein individuals shape and form their self-concept and identity. Burrow and Hill (2009) discussed how finding a sense of purpose is a fundamental human drive and has been researched from many different fields across diverse literature. Schwartz, Cote and Arnett (2005) found that among emerging adults a greater sense of purpose was linked to more deliberate individualism. Experiences offered through school, music, sports, and work provide more opportunities to perform independently, severing parental influences and forming personal agency. The Youth Academy Café confirmed the importance of youth having a voice during this time as they expressed a sense of respect given them when their voices were heard and their ideas are listened to. These types of experiences create environments for youth development of purpose and meaning which are tied to well-being as indicated through studies performed by Ryan \& Deci (2001). Personal meaning has been shown to be closely tied to increased positive moods and well-being (King et al., 2006).

For youth to achieve a life of meaning they need motivational experiences that create life tools which promote motivation during this transitional time. There is a need to hold activities for youth to express their opinions which can give them confidence and help them set and achieve goals, providing a necessary sense of purpose and ultimately life direction. Activities like the Youth Café offer them opportunities to express themselves in a safe environment.

Empowerment can be thought of as a multi-level construct which consists of practical approaches and processes (Jennings, Parra-Medina, Hilfinger-Messias, \& McLoughlin, 2006). As indicated in the findings of this study, empowerment could involve providing opportunities for adults or older youth to share responsibility and power with young people. An existing rationale in society today is that adults "know best", that adults' greater knowledge and experience have positioned them to provide guidance and direction (Larson, Walker, \& Pearce, 
2005). That is not necessarily the case. Enabling youth to express themselves by sharing responsibilities/power creates opportunities for youth and adults to collaborate (Camino, 2000). This will enhance their self-actualization and their influence in the community. Jennings et al. (2006) also noted that, the key dimensions of youth empowerment include: 1) safe and welcoming environment, 2) meaningful participation and engagement, 3) equitable balance of power between youth and adults, 4) opportunities for critical reflection, 5) engaging in sociopolitical processes to affect change, and 6) integration of both individual and community empowerment. The rationale for these aforementioned dimensions of youth empowerment is to encourage youth to take charge of their lives which involves: a) being aware of their situations; b) making informed decision(s); and c) taking appropriate actions to address those situations. As also noted in the findings, youth need their voices to be heard and acted upon. Therefore, there is a need for youth empowerment in order to create an opportunity for young people to experience participation (voice) and self-determination (choice) (Wilson et al., 2007).

The need for youth to improve their ways of gaining knowledge and being aware of different opportunities were highlighted in the findings. The rationale of this study indicates that engaging youth in targeted programs (e.g. Youth Academy Café) could serve as a platform for them to identify ways to improve their knowledge of various trends and issues. Furthermore, engaging young people in meaningful activities and programs could expose and help them again an awareness of different learning opportunities that might have gone unnoticed (Quinn, 1999). The Youth Academy Café program provided an opportunity for young people to identify a need to acquire more knowledge in different areas and aspects. Overall, it is evident that youth are willing to explore and learn which also indicates the need for the continuous development of programs.

The rapid ever-changing dynamic of social media and technology may be one of the biggest challenges for this population. Youth introduce themselves and interact on social media sites through designing their profile, adding friends and allowing others to comment on their activities. Though each site is different, the inventors of social media sites know and understand that it is important to "hook" youth for the site to be successful. Social norms emerge through these social media networks when youth develop "situational definitions, as people learn to read cues from the environment and the people present to understand what is appropriate behavior" (Boyd, 2007: p. 128). The significance of learning to communicate, manage impressions, and gage others reactions through social media sites is a "critical social skill that is honed through experience" (Boyd, 2007: p. 128). Signals and cues that take place in face to face interactions are different and are often lacking in the online world and can take on contrasting meanings. Learning to navigate and interpret social media sites is a rite of passage for today's youth as they interact in diverse social environments and hone their skills to developing appropriate behaviors. 
The students in the Youth Academy Café discussed social media as ever-changing and referred to the mode of communication as something they did not take too seriously. Ito and Ebrary, Inc, 2009, described the social media experience as differing levels of investment where youth hang out, mess around, and geek out in a way that "integrates an understanding of technical, social, and cultural patterns" (p. 36). The participants in the Youth Academy Café referred to social media as a leisure activity and a way to find out what activities or items of interest were going on in their daily lives. However, it is worthwhile to continue the conversation on the significance and impact of social media as "creating and networking online content is becoming, for many, an integral means of managing one's identity, lifestyle and social relations" (Livingstone, 2008: p. 4).

The need for physical wellness was echoed in the findings, not only because it is a relevant part of youthful life but also because it is a necessity for an effective and satisfying quality of life. Therefore, communities are called upon to create and support avenues or opportunities for youth to pleasurably thrive in physical wellness and hence quality of youthful life. It is imperative to develop strategies where physical wellness for youth is less stressful and devoid of pressure. Physical wellness of the youth within a community would not only benefit the individual but would most likely become a healthy communal productive asset in the long run. Youthful physical wellness habits are lured to adulthood (Sallis \& McKenzie, 1991).

Youth, like all others require a sense of place or community which they can gather. It is important in building community to have a gathering place. Such a place does not have to be a physical location but rather any means that provides the opportunity for individuals to coalesce-mingle, unite, join together and blend-with one another. In this Youth Academy Café the participants voiced a need for a gathering place. In a society which is increasingly technology driven, wherein youth are largely connected to one another through the use of social media, these portals become their gathering place. Such places provide "a particular space which is covered with meanings and values by the users" (Najafi \& Shariff, 2011: p. 1100). Other places where youth have gathered in the past include, schools, churches, youth centers/recreation centers, parks, shopping malls, movie theaters, swimming pools and each other's homes. These settings or places provided a context for youth to derive meaning from their environment.

Gaining the voices of youth is an important function for program planners, government officials and policy makers as well as the citizenry as a whole. Providing a stage for youth to convey their voice will enable them to engage in community life. The opportunity for youth to express themselves will enhance their identity and positioning in the community (Arnold, Dolenc, \& Wells, 2012). As a form of engagement, listening to the voices of youth creates meaning and contributes to positive youth development (Bundick, 2011). The Youth Academy Café provided opportunities for the participants to express themselves, 
listen to others and share their thinking, ideas and experiences with each other and community members.

\section{Future Research}

This method of applied research has provided an opportunity to engage community members in a meaningful and relevant fashion. It has also provided opportunities to consider future research activities. Among those, they include segmenting various population groupings. For example, an investigation could be undertaken with youths in faith-based organizations which are historical or traditional settings for such programs. Also, segmentation could occur according to gender, or racial or ethnic groupings. Of course finding ways to hear diverse voices to create understanding might also be a focus of future research activities. There are simply a myriad of combinations of individuals, groupings and settings that can be the focus of future research.

In addition, careful reconsideration of the questions asked to prompt discussion might be acknowledged. A focus on specific problems might be considered. In some respect, asking one set of questions leading to others as often occurs when opening dialogue is encouraged. In this way, future research is endless with opportunities to probe many different topics, subjects, issues and concerns.

\section{Conflicts of Interest}

The authors declare no conflicts of interest regarding the publication of this paper.

\section{References}

Arnett, J. J. (2006). Emerging Adulthood: Understanding the New Way of Coming of Age. In J. J. Arnett \& J. L. Tanner (Eds.), Emerging Adults in America: Coming of Age in the 21st Century (pp. 3-19). Washington DC, US: American Psychological Association.

Arnold, E. M., Dolenc, B., \& Welles, E. E. (2012). Youth Community Engagement: A Recipe for Success. Journal of Community Engagement and Scholarship, 1, 58-65.

Baumeister, R. F., Vohs, K. D., Aaker, J. L., \& Garbinsky, E. N. (2013). Some Key Differences between a Happy Life and a Meaningful Life. The Journal of Positive Psychology, 8, 505-516. https://doi.org/10.1080/17439760.2013.830764

Blum, R. W., Libbey, H. P., Bishop, J. H., \& Bishop, M. (2004). School Connectedness-Strengthening Health and Education Outcomes for Teenagers. Journal of School Health, 74, 231-235. https://doi.org/10.1111/j.1746-1561.2004.tb08278.x

Boyd, D. (2007). Why Youth (Heart) Social Network Sites: The Role of Networked Publics in Teenage Social Life. MacArthur Foundation Series on Digital Learning-Youth, Identity, and Digital Media, 119, 142.

Brown, J., \& Isaacs, D. (2005). The World Café: Shaping Our Future through Conversations that Matter. San Francisco: Berrett-Koehler.

Bundick, M. J. (2011). Extracurricular Activities, Positive Youth Development, and the Role of Meaningfulness of Engagement. The Journal of Positive Psychology, 6, 57-74. https://doi.org/10.1080/17439760.2010.536775 
Burrow, A. L., \& Hill, P. L. (2009). Youth Purpose as Identity Capital for Daily Experiences and Well-Being. Manuscript Submitted for Publication.

Camino, L. A. (2000). Youth-Adult Partnerships: Entering New Territory in Community Work and Research. Applied Developmental Science, 4, 11-20. https://doi.org/10.1207/S1532480XADS04Suppl_2

Christens, B. D., \& Peterson, N. A. (2012). The Role of Empowerment in Youth Development: A Study of Sociopolitical Control as Mediator of Ecological Systems' Influence on Developmental Outcomes. Journal of Youth and Adolescence, 41, 623-635. https://doi.org/10.1007/s10964-011-9724-9

Collins, A., \& Halverson, R. (2018). Rethinking Education in the Age of Technology: The Digital Revolution and Schooling in America. Teachers College Press.

Creswell, J. W. (2014). Research Design: Qualitative \& Quantitative Approaches. Sage Publications, Inc.

Cunningham, M., \& Rious, J. B. (2015). Listening to the Voices of Young People: Implications for Working in Diverse Communities. American Journal of Orthopsychiatry, 85, S86. https://doi.org/10.1037/ort0000132

Eccles, J., \& Gootman, J. A. (2002). Community Programs to Promote Youth Development.

Edginton, C. R., Kowalski, C. L., \& Randall, S. W. (2005). Youth Work: Emerging Perspectives in Youth Development. Urbana, 51, 61801.

Evans, S. D. (2007). Youth Sense of Community: Voice and Power in Community Contexts. Journal of Community Psychology, 35, 693-709. https://doi.org/10.1002/jcop.20173

Hamilton, S. F., Hamilton, M. A., \& Pittman, K. (2004). Principles for Youth Development. The Youth Development Handbook: Coming of Age in American Communities, 2, 3-22.

Hettler, B. (1976). The Six Dimensions of Wellness Model. http://www.NationalWellness.org

Ito, M., \& Ebrary, Inc. (2009). Hanging Out, Messing Around, and Geeking Out: Kids Living and Learning with New Media. Cambridge, MA: MIT Press.

Jennings, L. B., Parra-Medina, D. M., Hilfinger-Messias, D. K., \& McLoughlin, K. (2006). Toward a Critical Social Theory of Youth Empowerment. Journal of Community Practice, 14, 31-55. https://doi.org/10.1300/J125v14n01_03

Keniston, K. (1971). Psychological Development and Historical Change. The Journal of Interdisciplinary History, 2, 329-345.

King, L. A., Hicks, J. A., Krull, J., \& Del Gaiso, A. K. (2006). Positive Affect and the Experience of Meaning in Life. Journal of Personality and Social Psychology, 90, 179-196. https://doi.org/10.1037/0022-3514.90.1.179

Lambdin, D., \& Erwin, H. (2007). School Wellness Policy: Community Connections. Journal of Physical Education, Recreation \& Dance, 78, 29-32. https://doi.org/10.1080/07303084.2007.10598038

Larson, R. W. (2000). Toward a Psychology of Positive Youth Development. American Psychologist, 55, 170. https://doi.org/10.1037/0003-066X.55.1.170

Larson, R., Walker, K., \& Pearce, N. (2005). A Comparison of Youth-Driven and Adult-Driven Youth Programs: Balancing Inputs from Youth and Adults. Journal of Community Psychology, 33, 57-74. https://doi.org/10.1002/jcop.20035

Livingstone, S. (2008). Taking Risky Opportunities in Youthful Content Creation: Tee- 
nagers' Use of Social Networking Sites for Intimacy, Privacy and Self-Expression. New Media \& Society, 10, 393-411. https://doi.org/10.1177/1461444808089415

MacKenzie, M. J., \& Baumeister, R. F. (2014). Meaning in Life: Nature, Needs, and Myths. In Meaning in Positive and Existential Psychology (pp. 25-37). New York, NY: Springer. https://doi.org/10.1007/978-1-4939-0308-5_2

Najafi, M., \& Shariff, M. K. B. M. (2011). The Concept of Place and Sense of Place in Architectural Studies. International Journal of Human and Social Sciences, 6, 1100-1106.

Nugent, R. (2005). Youth in a Global World. World, 1, 1-845.

O'Keeffe, G. S., \& Clarke-Pearson, K. (2011). Clinical Report-The Impact of Social Media on Children, Adolescents, and Families. Pediatrics, 127, 800-804.

Peer Relations Study Group University of Wisconsin-Madison (2017). Middle Schoolers and Social Media: A Report of the Early Adolescents and Social Media Study. https://website.education.wisc.edu/prsg/wp-content/uploads/2017/08/Newsletter-Early -Adol-Social-Media-6-28-17.pdf

Putnam, R. D. (2017). Social Capital Primer. http://robertdputnam.com/bowling-alone/social-capital-primer/

Quinn, J. (1999). Where Need Meets Opportunity: Youth Development Programs for Early Teens. The Future of Children, 9, 96-116. https://doi.org/10.2307/1602709

Roche, J., Tucker, S., Flynn, R., \& Thomson, R. (Eds.). (2004). Youth in Society: Contemporary Theory, Policy and Practice. Sage.

Ryan, R. M., \& Deci, E. L. (2001). On Happiness and Human Potentials: A Review of Research on Hedonic and Eudaimonic Well-Being. Annual Review of Psychology, 52, 141-166. https://doi.org/10.1146/annurev.psych.52.1.141

Sallis, J. F., \& McKenzie, T. L. (1991). Physical Education's Role in Public Health. Research Quarterly for Exercise and Sport, 62, 124-137. https://doi.org/10.1080/02701367.1991.10608701

Schwartz, S. J., Cote, J. E., \& Arnett, J. (2005). Identity and Agency in Emerging Adulthood: Two Developmental Routes in the Individualization Process. Youth and Society, 37, 201-229. https://doi.org/10.1177/0044118X05275965

Steinfield, C., Ellison, N. B., \& Lampe, C. (2008). Social Capital, Self-Esteem, and Use of Online Social Network Sites: A Longitudinal Analysis. Journal of Applied Developmental Psychology, 29, 434-445. https://doi.org/10.1016/j.appdev.2008.07.002

United Nations Educational, Scientific and Cultural Organization, UNESCO. (2017). What Do We Mean by "Youth"?

http://www.unesco.org/new/en/social-and-human-sciences/themes/youth/youth-defini tion/

Valkenburg, P. M., Peter, J., \& Schouten, A. P. (2006). Friend Networking Sites and Their Relationship to Adolescents' Well-Being and Social Self-Esteem. CyberPsychology \& Behavior, 9, 584-590. https://doi.org/10.1089/cpb.2006.9.584

Waterloo Schools at a Glance. (2015). http://www.waterlooschools.org/demographics/

Wilson, N., Dasho, S., Martin, A. C., Wallerstein, N., Wang, C. C., \& Minkler, M. (2007). Engaging Young Adolescents in Social Action through Photovoice: The Youth Empowerment Strategies (YES!) Project. The Journal of Early Adolescence, 27, 241-261. https://doi.org/10.1177/0272431606294834

World Café Foundation (2015). Café on the Go! A Quick Reference Guide for Hosting World Café. http://www.theworldcafe.com/wp-content/uploads/2015/07/Cafe-To-Go-Revised.pdf 